\title{
Physiological parameters to select upland rice genotypes for tolerance to water deficit
}

\author{
Cleber Morais Guimarães ${ }^{(1)}$, Luís Fernando Stone ${ }^{(1)}$, Adriano Pereira de Castro(1) \\ and Odilon Peixoto de Morais Júnior(2)
}

\begin{abstract}
(1)EmbrapaArroze Feijão, Rodovia GO-462, Km 12, CEP75375-000 Santo Antônio de Goiás, GO, Brazil. E-mail: cleber.guimaraes@embrapa.br, luis.stone@embrapa.br, adriano.castro@embrapa.br (2)Universidade Estadual de Goiás, Unidade Universitária de Ipameri, Fazenda Experimental, Rodovia GO-330, Km 241, Anel Viário, CEP 75780-000 Ipameri, GO, Brazil. E-mail: odilon.agro@hotmail.com
\end{abstract}

\begin{abstract}
The objective of this work was to evaluate the feasibility of using physiological parameters for water deficit tolerance, as an auxiliary method for selection of upland rice genotypes. Two experiments - with or without water deficit - were carried out in Porangatu, in the state of Goiás, Brazil; the water deficit experiment received about half of irrigation that was applied to the well-watered experiment. Four genotypes with different tolerance levels to water stress were evaluated. The UPLRI 7, B6144F-MR-6-0-0, and IR80312-6-B-3-2-B genotypes, under water stress conditions, during the day, showed lower stomatal diffusive resistance, higher leaf water potential, and lower leaf temperature than the control. These genotypes showed the highest grain yields under water stress conditions, which were 534, 601, and $636 \mathrm{~kg} \mathrm{ha}^{-1}$, respectively, and did not differ significantly among them. They also showed lower drought susceptibility index than the other genotypes. 'BRS Soberana' (susceptible control) was totally unproductive under drought conditions. Leaf temperature is a easy-read parameter correlated to plant-water status, viable for selecting rice genotypes for water deficit tolerance.
\end{abstract}

Index terms: Oryza sativa, leaf diffusive resistance, leaf temperature, leaf-water potential.

\section{Parâmetros fisiológicos para selecionar genótipos de arroz quanto à tolerância ao deficit hídrico}

\begin{abstract}
Resumo - O objetivo deste trabalho foi avaliar a possibilidade de uso de parâmetros fisiológicos de tolerância à deficiência hídrica como método auxiliar na seleção de genótipos de arroz de terras altas. Dois experimentos um com e outro sem deficit hídrico - foram realizados em Porangatu, GO; o com deficit hídrico recebeu cerca da metade da irrigação que foi aplicada ao tratamento bem irrigado. Avaliaram-se quatro genótipos com diferentes níveis de tolerância ao estresse hídrico. Os genótipos UPLRI 7, B6144F-MR-6-0-0 e IR80312-6-B-3-2-B, em condições de estresse hídrico ao longo do dia, apresentaram menor resistência difusiva estomática, maior potencial de água nas folhas e menor temperatura das folhas do que a testemunha. Esses genótipos apresentaram as maiores produtividades em condições de deficiência hídrica, que foram respectivamente 534, 601 e $636 \mathrm{~kg} \mathrm{ha}^{-1}$, e não diferiram significativamente entre si. Eles também apresentaram menores índices de susceptibilidade à seca do que os outros genótipos. 'BRS Soberana' (testemunha suscetível) foi totalmente improdutiva em condições de deficiência hídrica. A temperatura das folhas é um parâmetro de fácil leitura correlacionado à condição hídrica da planta, viável para selecionar genótipos de arroz quanto à tolerância ao deficit hídrico.
\end{abstract}

Termos para indexação: Oryza sativa, resistência difusiva foliar, temperatura foliar, potencial de água na folha.

\section{Introduction}

Rice is the basic food for over half of the world population. It is widely cultivated in conditions subjected to water stress (Manickavelu et al., 2006), both in Asia and in Brazilian upland systems. Upland rice encompasses $12 \%$ of global rice production area, and it is of a proportionately greater importance in
Africa and Latin America, where it accounts for around 40 and $45 \%$ of the rice-growing areas, respectively (Bernier et al., 2008).

Productivity in these areas is severely affected by water stress, due to unpredictable, insufficient, and uneven rainfall during the growing period. To reduce the risk for the crop, the use of new cultivars, with a greater capacity to adapt to the irregular distribution of 
rainfall, is recommended, besides the most appropriate practices which enable plants for better use of soil water (Manickavelu et al., 2006).

Gains from rice improvement for water-stress tolerance have been modest. Plant breeders rely on direct selection for grain yield as the main criterion for selection. That process might be made more efficient by the use of indirect traits associated with water deficit (Jongdee et al., 2006). The incorporation of secondary components in phenotyping for water-deficit tolerance, in the selection criteria adopted in conventional breeding programs conducted in adequately prepared environments, from the standpoint of water for such trait to be expressed, may contribute to the selection of plants for areas with occurrence of irregular rainfall distribution (Manickavelu et al., 2006).

The adaptation to water stress, among other factors, results from the maintenance of good water status in plant tissues, which can be evaluated by leaf-water potential, stomatal diffusive resistance and leaf temperature. Guimarães et al. (2006) reported that a water-deficit tolerant common bean cultivar, subjected to water-stress conditions, showed higher leaf-water potential and lower stomatal diffusive resistances than a susceptible cultivar.

Leaf temperature is a function of leaf energy balance; and the higher is the leaf temperature, the lower is the energy loss. This loss occurs in several ways, one of which is the transpiration, which is more intense as better is plant-water status. The infrared thermometry can thus infer the water status of the plant (Jones, 2007), which stands out because of its rapid and nondestructive measurement, in comparison to those of rolling leaves, wilt, change color, thickness, diameter stem, stomatal diffusive resistance, and leaf-water potential,

The objective of this work was to evaluate the feasibility of using physiological parameters of water deficit tolerance, as an auxiliary method for the selection of upland rice genotypes.

\section{Materials and Methods}

Two experiments were carried out in a Latossolo Vermelho (Typic Hapludox) (Santos et al., 2006), at Embrapa Arroz e Feijão drought-phenotyping site, located at Emater experimental station, in Porangatu, $\mathrm{GO}$, Brazil. The experimental design was performed in a randomized complete block, with four replicates, and one experiment were with and the other were without water deficit. Four genotypes were evaluated: 'BRS Soberana', an upland cultivar of the Japonica group, and the lines B6144F-MR-6-0-0, IR80312-6-B-3-2-B, and UPLRI 7 (UPLRI 7) of the Indica group. 'BRS Soberana' was susceptible to water deficit (Heinemann et al., 2011), and the lines were stres-tolerant to that (Guimarães et al., 2009).

The experiments were sown on 4/30/2009, in plots with six $5 \mathrm{~m}$ long rows, and $40 \mathrm{~cm}$ apart. Fertilization was applied at sowing at 20, 120 and $60 \mathrm{~kg} \mathrm{ha}^{-1}$ of $\mathrm{N}, \mathrm{P}_{2} \mathrm{O}_{5}$ and $\mathrm{K}_{2} \mathrm{O}$, respectively, and $30 \mathrm{~kg} \mathrm{~N}^{-1}$ as ammonium sulfate for top dressing, 45 days after emergence. Weed control was done via oxadiazon at $1,000 \mathrm{~g}$ a.i. ha $^{-1}$ at plant pre-emergency.

The experiment without water stress was well irrigated throughout the plant development; and the experiment subjected to water stress was irrigated only up to 30 days after emergency, when water deficiency was imposed from the final growing season stage up to harvest. For this, irrigations were applied on the first experiment, and during the phase without water deficit of the second experiment, by applying about $25 \mathrm{~mm}$ of water irrigation, when soil-water potential at $0.15 \mathrm{~m}$ depth reached $-0.025 \mathrm{MPa}$ (Pinheiro et al., 2006). In the water stress period, approximately half of the amount of irrigation water was furnished to the experiment under water stress conditions. During the crop cycle, there were no rain, and soil-water was totally controlled.

Leaf-water potential, photosynthetically active solar radiation, stomatal diffusive resistance, and leaf temperature were monitored on $66^{\text {th }}$ and $79^{\text {th }}$ days after emergency. Leaf-water potential, photosynthetically active solar radiation, and temperature were monitored continuously from dawn to sunset, while the monitoring of stomatal diffusive resistance began after the disappearance of dew, to not compromise the readings. Stomatal diffusive resistance $\left(\mathrm{s} \mathrm{m}^{-1}\right)$ was measured in two samples, on the superior surface of fully expanded, apical leaves, at good solar exposure, with SC-1 leaf porometer (Decagon Devices, Pullman, WA, USA). Leaf-water potential (MPa) was determined with pressure chambers, model 3005 (Soilmoisture Equipment, Santa Barbara, CA, USA), also on fully expanded, apical leaves. The value of leaf-water potential was the average of two individual 
readings. The equipment was installed in the center of the experiment, to minimize the time between sample collection and readings of water potential in leaves; all recommended precautions to this operation were taken. Leaf temperatures $\left({ }^{\circ} \mathrm{C}\right)$ were measured with a model 66 infrared thermometer (Fluke Corporation, Everett, WA, USA), and the considered value was the average of two individual readings on fully expanded upper leaves. The photosynthetically active radiation $\left(\mu \mathrm{E} \mathrm{s}^{-1} \mathrm{~m}^{-2}\right)$ was measured, with both LI-191SB Line Quantum solar sensor and LI-1776 solar monitor (LI-COR, Lincoln, NE, USA). In addition, grain yield was determined on four central lines of each plot, leaving a $0.50 \mathrm{~m}$ border at both ends, and based on it, the drought susceptibility index was determined according to Fischer \& Maurer (1978).

The joint variance analysis of the two experiments was performed for grain yield and means were compared by Tukey's test, at 5\% probability.

\section{Results and Discussion}

Based on the joint variance analysis, the genotypes were differently affected by water treatments because genotype $\mathrm{x}$ water treatment interaction was significant (Table 1). Lafitte et al. (2006) and Guimarães et al. (2013) also observed that rice genotypes showed different responses to water deficit in relation to grain yield.

Genotypes were significantly affected by both water treatments. The average productivity of plants under water-deficit treatment was $443 \mathrm{~kg} \mathrm{ha}^{-1}$, and at the treatment without water deficit, it was $3,121 \mathrm{~kg} \mathrm{ha}^{-1}$ (Table 2), so, the average of water stress depression on grain yield was $85.8 \%$. The genotypes UPLRI 7, B6144F-MR-6-0-0, and IR80312-6-B-3-2-B had the highest yields, which were 534, 601, and $636 \mathrm{~kg} \mathrm{ha}^{-1}$ respectively, under water stress conditions, and did not differ significantly among them. They also showed the lowest drought susceptibility index. 'BRS Soberana' (susceptible control) was totally unproductive at the applied level of water deficit.

Under well-irrigated conditions, there was not a remarkable reduction of leaf-water potential during the day, as observed under water stress (Figure 1). Minimum potential of the genotypes were also similar, $-2.30,-2.24,-2.08$, and $-2.16 \mathrm{MPa}$, for 'BRS Soberana', B6144F-MR-6-0-0, IR80312-6-B-3-2-B, and UPLRI 7, respectively. Under water stress conditions, the values observed at 7:30 h were $-1.85,-1.39,-1.68$, and $-1.49 \mathrm{MPa}$, for the same genotypes, respectively. Minimum leaf-water potential under this treatment were $-2.81,-2.59,-2.35$, and $-2.50 \mathrm{MPa}$ for 'BRS Soberana', B6144F-MR-6-0-0, IR80312-6-B-3-2-B, and UPLRI 7, respectively. These results agree with those found by He \& Serraj (2012), who observed that under water stress there was a reduction of leaf-water potential by an average of $0.43 \mathrm{MPa}$, compared to the well-watered treatment.

The most productive genotypes under water stress conditions showed higher leaf-water potential during the day, while 'BRS Soberana' showed lower leaf-water potential, in comparison to the others genotypes. 'BRS Soberana' did not show the level of water deficit recuperation, with the reduction of solar radiation (Figure 2), as observed for the other genotypes; its water potential at 18:00 $\mathrm{h}$ was $-2.49 \mathrm{MPa}$, while the average water potential in the other genotypes was $-2.02 \mathrm{MPa}$. Similar results were observed by Kato et al. (2011), who found that a water stress tolerant genotype increased leaf-water potential by $30 \%$, in comparison to a susceptible one, under water deficit conditions (when soil moisture at $0,40 \mathrm{~m}$ reached $-70 \mathrm{kPa}$ ). Maintenance of high leaf-water potential is associated with large

Table 1. Summary of analysis of variance for grain yield.

\begin{tabular}{lcc}
\hline Source of variation & DF & Mean square \\
\hline Block & 3 & 63,765 \\
Water treatment (WS) & 1 & $57,381,506^{* *}$ \\
Genotype (G) & 3 & $3,575,147^{* *}$ \\
WS x G & 3 & $1,208,225^{* *}$ \\
Error & 21 & 155,109 \\
\hline CV $(\%)$ & & 22.1 \\
\hline
\end{tabular}

**Significant by the $\mathrm{F}$ test, at $1 \%$ probability.

Table 2. Grain yield $\left(\mathrm{kg} \mathrm{ha}^{-1}\right)$ and drought susceptibility index (DSI) of upland rice genotypes, with or without water stress, from the final growing season stage up to harvest ${ }^{(1)}$.

\begin{tabular}{|c|c|c|c|}
\hline \multirow[t]{2}{*}{ Genotypes } & With water stress & Without water stress & \multirow[t]{2}{*}{ DSI } \\
\hline & \multicolumn{2}{|c|}{ 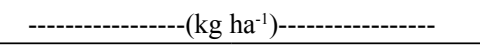 } & \\
\hline BRS Soberana & $0 \mathrm{~b}$ & $1,617 \mathrm{~b}$ & 1.16 \\
\hline B6144F-MR-6-0-0 & $601 \mathrm{a}$ & $4,063 \mathrm{a}$ & 0.99 \\
\hline IR80312-6-B-3-2-B & $636 \mathrm{a}$ & $3,324 \mathrm{a}$ & 0.94 \\
\hline$\underline{\text { UPLRI } 7}$ & $534 \mathrm{a}$ & $3,481 \mathrm{a}$ & 0.98 \\
\hline Average & 443 & 3,121 & \\
\hline
\end{tabular}


xylem size and, hence, with higher internal water conductance (Sibounheuang et al., 2006).

According to Bernier et al. (2008) and He \& Serraj (2012), leaf-water potential is strongly correlated with spikelet sterility under water stress. These last authors also found that grain yield was highly associated with spikelet fertility and leaf-water potential. Because of this, most of the genotypes, identified as tolerant to water stress, maintained a significantly higher leaf-water potential than the more susceptible genotypes (Kato et al., 2007). They had higher fertility of panicles, and the highest percentage of well-formed grains, which accounts for their higher productivity.

The effect of water stress on the plant depends on the stage it occurs. If it coincides with the anther development, genotypes with higher leaf-water potential will have a greater quantity of pollen grains
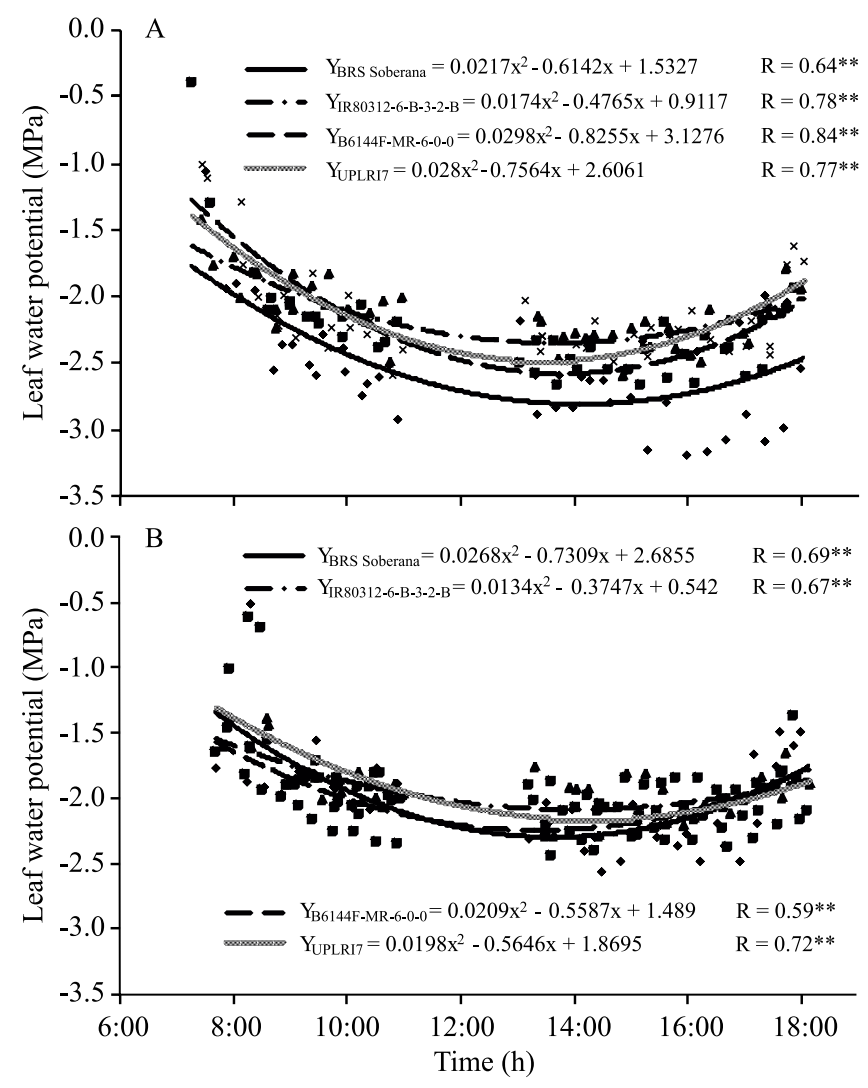

Figure 1. Diurnal variation of leaf-water potential in the upland rice genotypes 'BRS Soberana', B6144F-MR-6-0-0, IR80312-6-B-3-2-B, UPLRI 7, on 07/15/2009 and 07/28/2009, at 66 and 79 days after emergency, respectively: A, with water stress; B, without water stress. and, consequently, a higher yield (Nguyen \& Sutton, 2009). These authors observed $34 \%$ average reduction of grain set, under water stress conditions, at $-0,90$ MPa leaf-water potential, in comparison to the control.

When leaf-water potential decreases, at the panicle emergence stage, it affects panicle exsertion and anthesis dehiscence, also occurring spikelet desiccation, which results in sterility increase. If low leaf-water potential occurs after anthesis, pollination, and fertilization, it may induce embryo abortion and reduce grain weight (He \& Serraj, 2012). The best productivity of the genotypes B6144F-MR-6-0-0, IR80312-6-B-3-2-B, and UPLRI 7 can be explained by the maintenance of leaf-water potential, before and after the emergence of panicles, which improved the overall water condition of plants as a result of the best establishment of grains with higher weight. These water conditions induced better fertility of pollen grains, emission of panicles, pollination, fertilization, and grain formation, by reducing embryo abortion.

The temperature of leaves $\left(T_{1}\right)$ responded to the oscillations of solar radiation, inferred by the photosynthetic active radiation (Figure 2), in both water treatments, and, irrespectively of the water treatments and genotypes, it varied throughout the day, according to quadratic equations (Figure 3 ).

The well-irrigated plants showed lower increase of leaf temperature, due to a greater heat loss with the occurrence of higher transpiration. In this treatment, genotypes had similar leaf temperatures throughout the day, with a slight tendency to higher temperatures showed by 'BRS Soberana'. This fact was observed

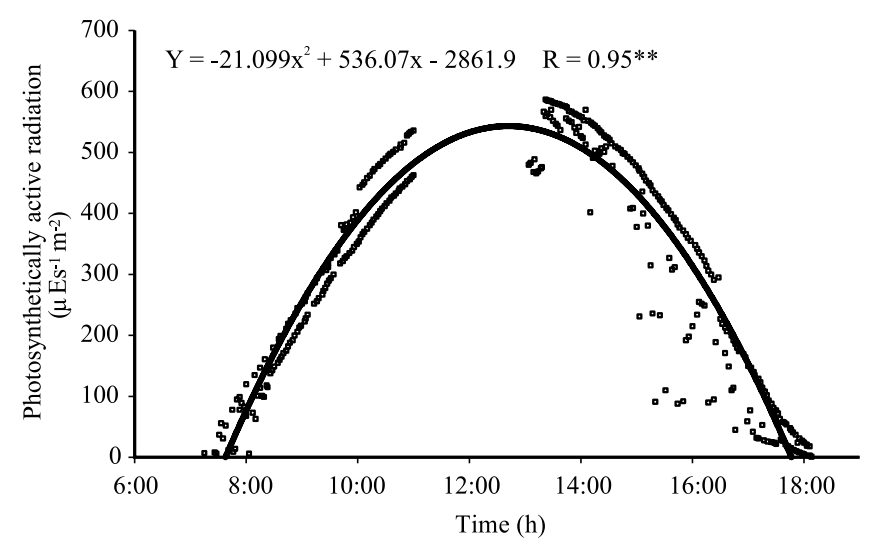

Figure 2. Average photosynthetically active solar radiation on $07 / 15 / 2009$ (full square), and on 07/28/2009 (leaked square), at 66 and 79 days after emergency, respectively.

Pesq. agropec. bras., Brasília, v.50, n.7, p.534-540, jul. 2015 DOI: $10.1590 / \mathrm{S} 0100-204 X 2015000700003$ 
after dawn, at 7:30 h, and lasted until 18:00 h, when the readings were finished.

Under water stress conditions, leaf temperature of genotypes was higher with the increase of solar radiation. At 7:30 $\mathrm{h}$, the genotypes had similar temperatures - about $18^{\circ} \mathrm{C}$; however, as solar radiation increased, leaf temperature increased with a greater intensity. Temperature increase was different among almost all genotypes. Leaf temperature difference between genotypes correlates with characters of water deficit tolerance (Liu et al., 2005; Hirayama et al, 2006). 'BRS Soberana' was heated more intensely, and its observed maximum temperature was $37.1^{\circ} \mathrm{C}$ at 13:42 $\mathrm{h}$. The other genotypes became also heated, but with lower intensity. Observed temperatures were $33.8,32.4$, and $33.7^{\circ} \mathrm{C}$ for IR80312-6-B-3-2-B, B6144F-MR-6-0-0, and UPLRI 7, respectively.
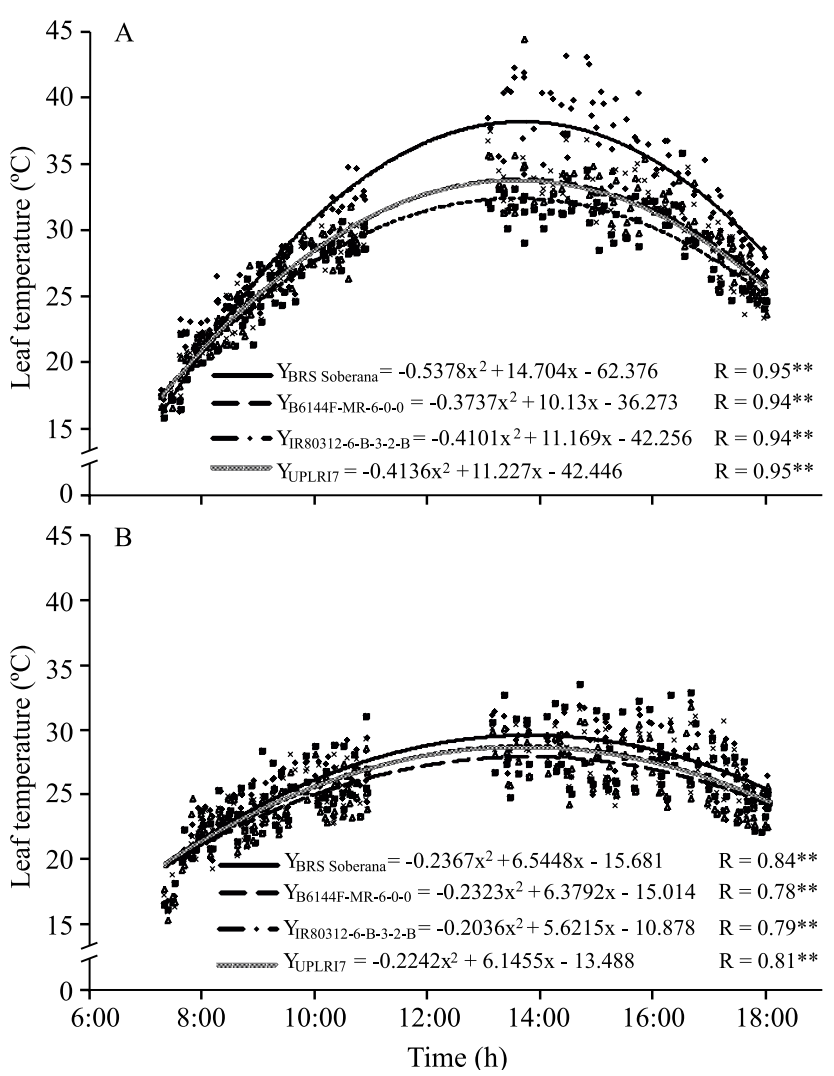

Figure 3. Diurnal variation of leaf temperature of the upland rice genotypes 'BRS Soberana', B6144F-MR-6-0-0, IR80312-6-B-3-2-B, UPLRI 7, on 07/15/2009 and 07/28/2009, at 66 and 79 days after emergency, respectively: $\mathrm{A}$, with water stress; B, without water stress.
At 18:00 h, when the observations were finished, 'BRS Soberana' kept high the leaf temperature (Figure $3 \mathrm{~A}$ ), which means that water status of plants had not fully recovered, since water potential in the leaves was not fully recovered in the treatment with water deficit (Figure 1 A).

In both water treatments, the leaf temperature of all genotypes varied linearly, as leaf-water potential decreased (Figure 4). The thermal sensitivity of leaves was higher in the water stress treatment than in the well-irrigated one, except for the line B6144F-MR-6-0-0, which had similar thermal sensitivity in both treatments. Thermal sensitivity of 'BRS Soberana', IR80312-6-B-3-2-B, B6144F-MR-6-0-0 and UPLRI 7, under water stress
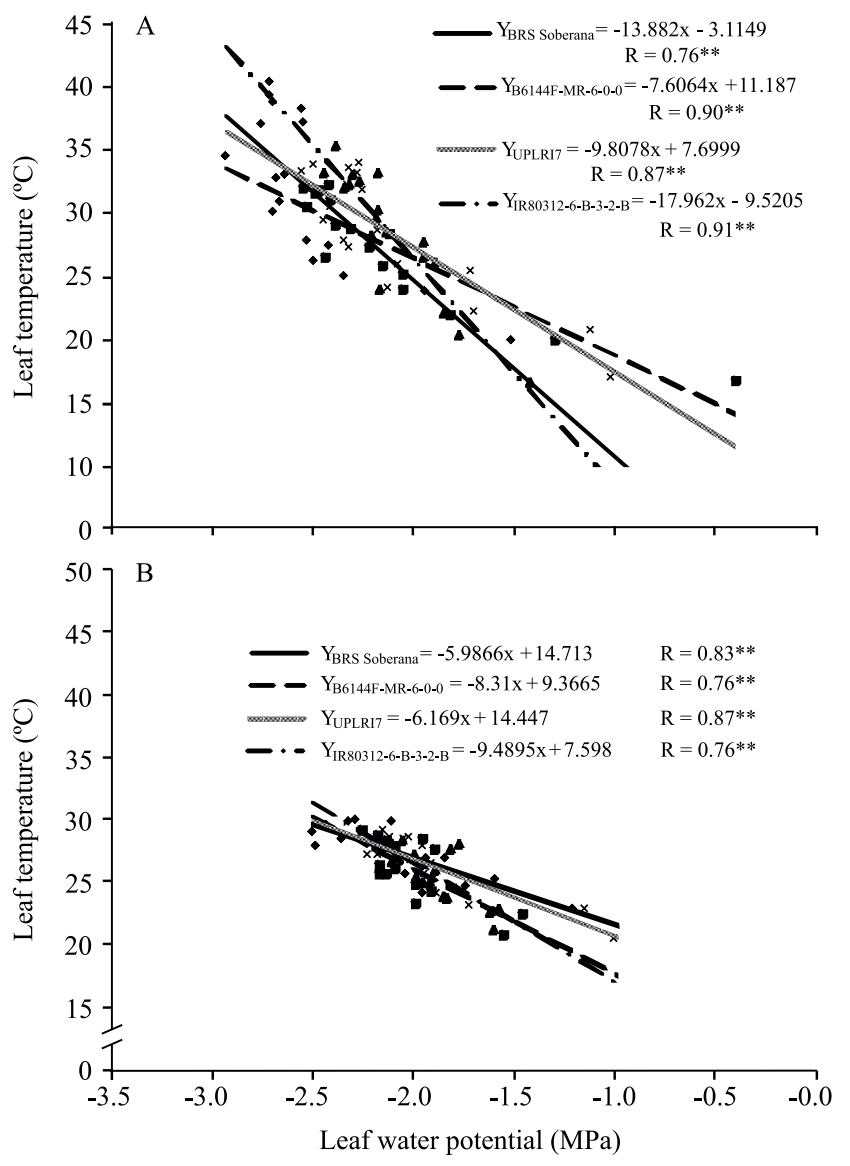

Figure 4. Leaf temperature variation of the upland rice genotypes 'BRS Soberana', B6144F-MR-6-0-0, IR80312-6-B-3-2-B, UPLRI 7: A, with the leaf-water potential under water stress; and $\mathrm{B}$, with the leaf-water potential without water stress. 
treatment were $13.9,18.0,7.6$, and $9.8^{\circ} \mathrm{C}$, respectively, to a reduction of leaf-water potential of $1 \mathrm{MPa}$, and $6.0,9.5,8.3$, and $6.2^{\circ} \mathrm{C}$, respectively, for the same genotypes under well-irrigated treatment.

The water deficit-tolerant genotypes, B6144F-MR-6-0-0, IR80312-6-B-3-2-B, and UPLRI 7, maintained under water stress showed better water conditions and higher leaf-water potential, probably because they have more efficient water use. The water deficit-tolerant genotypes are able to maintain better internal water status, either by taking up more water through a better root system, or by reducing the rate of plant-water use (Kamoshita et al., 2008). A vigorous root growth positively affects water uptake and, hence, maintains rice transpiration (Kato \& Okami, 2010) and keeps a lower rice leaf-temperature, ultimately stabilizing yield under water stress. Hirayama et al. (2006) also observed that the cultivars of upland rice with deeper root systems had lower leaf temperatures. These authors also found that leaf temperature was highly correlated with the transpiration rate and photosynthesis.

Additionally, Liu et al. (2005) and Guimarães et al. (2010) observed that grain yield and spikelet sterility were related to leaf temperature and that this varied between genotypes. They also observed that leaf temperature was highly correlated with indexes of visual water deficit-tolerance and wilting leaves. The authors concluded that leaf temperature constitutes a valuable tool for water deficit-tolerance phenotyping.

The values of stomatal diffusive resistance, in the predawn, were similar among the genotypes, they were close to $100 \mathrm{~s} \mathrm{~m}^{-1}$, and varied throughout the day according to quadratic mathematical models; for these values, the genotypes showed different maximum points (Figure 5). The genotypes IR80312-6-B-3-2-B, B6144F-MR-6-0-0 and UPLRI 7 had the highest stomatal diffusive resistance between 13:30 and 13:40 h, while 'BRS Soberana' kept a constant increase of stomatal diffusive resistance up to $16: 10 \mathrm{~h}$, when $333 \mathrm{~s} \mathrm{~m}^{-1}$ was observed for this parameter. This can be explained by the worse water status of this cultivar, as shown by its lower leaf-water potential throughout the day, as well as by the its worse recovery of water status (Figure 1) with the reduction of solar radiation, which was confirmed by leaf temperature (Figure 3 ).

The data are indicative that 'BRS Soberana' is more susceptible to water stress, which is showed by

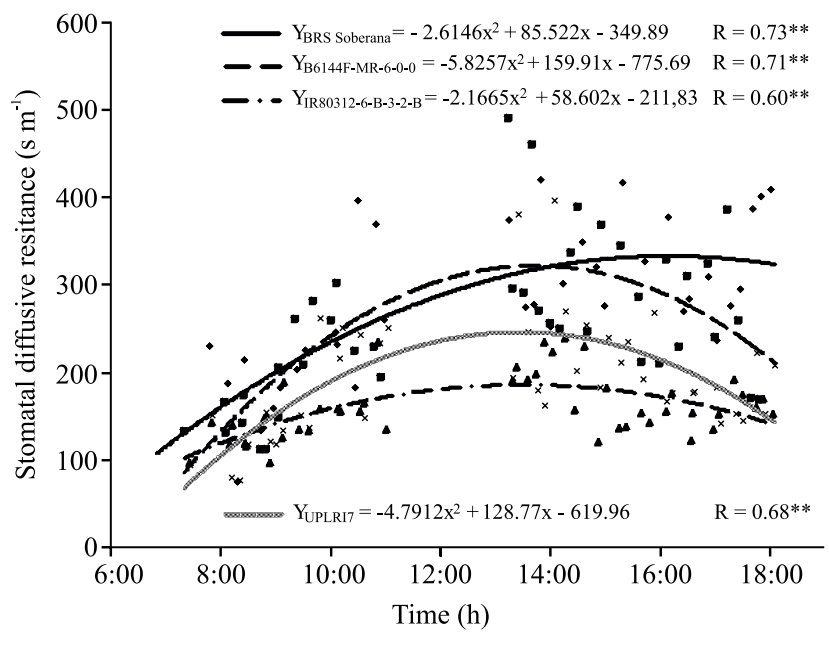

Figure 5. Diurnal variation of stomatal diffusive resistance of the upland rice genotypes 'BRS Soberana', B6144F-MR-6-0-0, IR80312-6-B-3-2-B, UPLRI 7, on $07 / 15 / 2009$ and $07 / 28 / 2009$, at 66 and 79 days after emergency, respectively, under water stress.

its higher stomatal diffusive resistance, during most of the day, in response to its worse water conditions, certainly by having a lower capacity of the soil water use. The most water stress-tolerant genotypes had lower stomatal diffusive resistance, mainly the lines IR80312-6-B-3-2-B and UPLRI 7, which also had better water conditions evaluated by leaf-water potential and leaf temperature, when subjected to water deficit.

\section{Conclusions}

1. Leaf-water potential, leaf temperature, and stomatal diffusive resistance are sensitive to water deficit, and they can be used to discriminate rice genotypes for tolerance to this kind of stress.

2. Leaf temperature is a easy-read parameter correlated to plant-water status, viable for selecting rice genotypes for water deficit tolerance.

\section{Acknowledgments}

To the Experimental Station of Empresa de Assistência Técnica e Extensão Rural (Emater), in Porangatu, GO, Brazil, for the provision of infrastructure; and to Ramatis Justino da Silva, for his assistance in the conduction of this research. 


\section{References}

BERNIER, J.; ATLIN, G.N.; SERRAJ, R.; KUMAR, A.; SPANER, D. Breeding upland rice for drought resistance. Journal of the Science of Food and Agriculture, v.88, p.927-939, 2008. DOI: 10.1002/jsfa.3153.

FISCHER, R.A.; MAURER, R. Drought resistance in spring wheat cultivars. I. Grain yield responses. Australian Journal of Agricultural Research, v.29, p.897-912, 1978. DOI: 10.1071/ AR9780897.

GUIMARÃES, C.M.; BRESEGHELlO, F.; CASTRO, A.P. de; STONE, L.F.; MORAIS JÚNIOR, O.P. de. Comportamento produtivo de linhagens de arroz do grupo indica sob irrigação adequada e sob deficiência hídrica. Santo Antônio de Goiás: Embrapa Arroz e Feijão, 2009. 4p. (Embrapa Arroz e Feijão. Comunicado técnico, 180).

GUIMARÃES, C.M.; STONE, L.F.; BRUNINI, O. Adaptação do feijoeiro comum (Phaseolus vulgaris L.) à seca. Revista Brasileira Engenharia Agrícola e Ambiental, v.10, p.70-75, 2006. DOI: 10.1590/S1415-43662006000100011.

GUIMARÃES, C.M.; STONE, L.F.; LORIEUX, M.; OLIVEIRA, J.P. de; ALENCAR, G.C. de O.; DIAS, R.A.A. Infrared thermometry for drought phenotyping of inter and intra specific upland rice lines. Revista Brasileira de Engenharia Agrícola e Ambiental, v.14, p.148-154, 2010. DOI: 10.1590/ S1415-43662010000200005.

GUIMARÃES, C.M.; STONE, L.F.; RANGEL, P.H.N.; SILVA, A.C. de L. Tolerance of upland rice genotypes to water deficit. Revista Brasileira de Engenharia Agrícola e Ambiental, v.17, p.805-810, 2013. DOI: 10.1590/S1415-43662013000800001.

HE, H.; SERRAJ, R. Involvement of peduncle elongation, anther dehiscence and spikelet sterility in upland rice response to reproductive-stage drought stress. Environmental and Experimental Botany, v.75, p.120-127, 2012. DOI: 10.1016/j. envexpbot.2011.09.004.

HEINEMANN, A.B.; STONE, L.F.; FAGERIA, N.K. Transpiration rate response to water deficit during vegetative and reproductive phases of upland rice cultivars. Scientia Agricola, v.68, p.24-30, 2011. DOI: 10.1590/S0103-90162011000100004.

HIRAYAMA, M.; WADA, Y.; NEMOTO, H. Estimation of drought tolerance based on leaf temperature in upland rice breeding. Breeding Science, v.56, p.47-54, 2006. DOI: 10.1270/jsbbs.56.47.

JONES, H.G. Monitoring plant and soil water status: established and novel methods revisited and their relevance to studies of drought tolerance. Journal of Experimental Botany, v.58, p.119-130, 2007. DOI: 10.1093/jxb/erl118.

JONGDEE, B.; PANTUWAN, G.; FUKAI, S.; FISCHER, K. Improving drought tolerance in rainfed lowland rice: an example from Thailand. Agricultural Water Management, v.80, p.225-240, 2006. DOI: 10.1016/j.agwat.2005.07.015.
KAMOSHITA, A.; BABU, R.C.; BOOPATHI, N.M.; FUKAI, S. Phenotypic and genotypic analysis of drought-resistance traits for development of rice cultivars adapted to rainfed environments. Field Crops Research, v.109, p.1-23, 2008. DOI: 10.1016/j. fcr.2008.06.010.

KATO, Y.; HENRY, A.; FUJITA, D.; KATSURA, K.; KOBAYASHI, N.; SERRAJ, R. Physiological characterization of introgression lines derived from an indica rice cultivar, IR64, adapted to drought and water-saving irrigation. Field Crops Research, v.123, p.130-138, 2011. DOI: 10.1016/j.fcr.2011.05.009.

KATO, Y.; KAMOSHITA, A.; YAMAGISHI, J. Evaluating the resistance of six rice cultivars to drought: restriction of deep rooting and the use of raised beds. Plant and Soil, v.300, p.149-161, 2007. DOI: 10.1007/s11104-007-9397-z.

KATO, Y.; OKAMI, M. Root growth dynamics and stomatal behavior of rice (Oryza sativa L.) grown under aerobic and flooded conditions. Field Crops Research, v.117, p.9-17, 2010. DOI: 10.1016/j.fcr.2009.12.003.

LAFITTE, H.R.; LI, Z.K.; VIJAYAKUMAR, C.H.M.; GAO, Y.M.; SHI, Y.; XU, J.L.; FU, B.Y.; YU, S.B.; ALI, A.J.; DOMINGO, J.; MAGHIRANG, R.; TORRES, R.; MACKILL, D. Improvement of rice drought tolerance through backcross breeding: evaluation of donors and selection in drought nurseries. Field Crops Research, v.97, p.77-86, 2006. DOI: 10.1016/j.fcr.2005.08.017.

LIU, H.; ZOU, G.; LIU, G.; HU, S.; LI, M.; YU, X.; MEI, H.; LUO, L. Correlation analysis and QTL identification for canopy temperature, leaf water potential and spikelet fertility in rice under contrasting moisture regimes. Chinese Science Bulletin, v.50, p.317-326, 2005. DOI: 10.1007/BF02897572.

MANICKAVELU, A.; NADARAJAN, N.; GANESH, S.K.; GNANAMALAR, R.P.; BABU, R.C. Drought tolerance in rice: morphological and molecular genetic consideration. Plant Growth Regulation, v.50, p.121-138, 2006. DOI: 10.1007/ s10725-006-9109-3.

NGUYEN, G.N.; SUTTON, B.G. Water deficit reduced fertility of young microspores resulting in a decline of viable mature pollen and grain set in rice. Journal of Agronomy and Crop Science, v.195, p.11-18, 2009. DOI: 10.1111/j.1439-037X.2008.00342.x.

PINHEIRO, B. da S.; CASTRO, E. da M. de; GUIMARÃES, C.M. Sustainability and profitability of aerobic rice production in Brazil. Field Crops Research, v.97, p.34-42, 2006. DOI: 10.1016/j. fcr.2005.08.013.

SANTOS, H.G. dos; JACOMINE, P.K.T.; ANJOS, L.H.C. dos; OLIVEIRA, V.A. de; OLIVEIRA, J.B. de; COELHO, M.R.; LUMBRERAS, J.F.; CUNHA, T.J.F. (Ed.). Sistema brasileiro de classificação de solos. 2.ed. Rio de Janeiro: Embrapa Solos, 2006. 306p.

SIBOUNHEUANG, V.; BASNAYAKE, J.; FUKAI, S. Genotypic consistency in the expression of leaf water potential in rice (Oryza sativa L.). Field Crops Research, v.97, p.142-154, 2006. DOI: 10.1016/j.fcr.2005.09.006.

Received on Octuber 31, 2014 and accepted on May 27, 2015

Pesq. agropec. bras., Brasília, v.50, n.7, p.534-540, jul. 2015

DOI: 10.1590/S0100-204X2015000700003 